\title{
Biotechnology rules: Spain falls into line
}

Barcelona. Spain's first biotechnology bill is to be debated by Parliament this autumn. It is expected to provoke controversy, as it fails to give either public interest groups or representatives from Spain's 17 autonomous regions any say in risk control.

The bill also fails to allocate responsibility for accidents to manufacturers of genetically modified products. As a result, some critics fear that farmers or other users of genetically manipulated organisms could be personally sued if things go wrong.

The bill is an attempt to incorporate two European Communities (EC) directives on the use of genetically manipulated organisms into Spanish law.

A National Commission on Biosecurity (CNB) will be set up, whose members will include expert scientists and representatives from six ministries: public works and transport (which is responsible for environmental affairs and which originally drafted the bill), health, agriculture, education and science, industry and the interior. However it excludes trade unions and environmental groups, contrary to the directives' recommendations

The bill also establishes a new licensing authority for genetically modified organisms, made up of officials from the ministries of transport, health, agriculture and industry. This authority would have full executive powers, and would not be bound by the CNB's reports on risk.

Spain's autonomous regions will maintain their responsibilities for regulating the

\section{German changes face opposition}

Munich. Germany's Social Democrats are threatening to block the passage of a proposed law revising the regulations covering genetic engineering when the law, which was approved by the country's federal Parliament (Bundestag) two weeks ago, is debated in its lower house, the Bundesrat, next month.

In particular, the Social Democrats who are in the minority in the Bundestag, which is dominated by the Christian Democrats, but have a majority in the Bundesrat, made up of representatives from the individual Länder - object to a newly added clause that would allow field experiments with genetically modified organisms without a public hearing.

The main aim of the new bill is to streamline current procedures for approving all genetic engineering experiments. It is being actively supported by the country's chemical and pharmaceutical industries (as well as by many research organizations) which argue that excessively rigid legislation is forcing companies to locate research and development activities in foreign countries.

According to the law put to the Bundestag, there would be a substantial reduction in the amount of paperwork required for experiments considered to present no risk or low risk. In addition, the obligatory two-month waiting period between registering a low-risk experiment and starting experiments would be halved (see Nature 359, 93; 1992).

Before the debate in the Bundestag, the Social Democrats had said that they were willing to accept the main changes contained in the bill, which had been under detailed technical discussion between scientists and politicians for nearly a year, but that they did not want to reduce the waiting period.

Only a few days before the bill appeared in Parliament, however, the Christian Democrats added a further clause, which had not been discussed with the opposition parties, allowing the release into the environment of genetically modified plants without a public hearing.

This sudden addition, which has been described by environmentalist groups as a "scandalously cloak and dagger" move, caused most Social Democrats to abstain from the final vote in the Bundestag, and two to vote against the bill.

If the Social Democrats persuade the Bundesrat to block the bill next month, it will go to a mediation committee between the two legislative bodies to reach a compromise. And if this happens, the revised law is unlikely to be passed, as hoped, by the end of this year.

Alison Abbott
London. Britain's biotechnology industry has persuaded a committee of the House of lation, much of it emanating from the European Commission in Brussels, is reducing its ability to compete effectively with companies in both the United States and Japan.

In a report published in London last week, the Lords Select Committee on Science and Technology delivered a strong attack on two directives issues by Brussels in 1990, one on the contained use of genetically manipulated organisms and the other on their controlled release, which are now required to form the basis of legislation in all member states.

The committee claims that both directives are unscientific in their content, impose an excessive burden on the research community and biotechnology companies, and fail to take into account critical comLords to back its claims that excessive regu- confined use of genetically altered products. But the authority's ruling on products released into the environment will apply nationally - another potential point of contention when it is debated in Parliament.

The exclusion of the autonomous regions from both the licensing authority and the CNB is certain to generate criticism, particularly from Catalonia. In 1990 , problems encountered with an experiment involving genetically engineered plants carried out by the Catalan government's Institute of Agriculture - including the fact that the crop spread beyond its confines - meant that the whole crop had to be burnt.

But the exclusion of the autonomous regions may be intended to allow the socialist government, which does not have a full majority in the national Parliament, to negotiate a consultative role for local governments within a broader package of political agreements.

Daniel Borillo, a lawyer specializing in gene laws, claims that the exclusion of many interest groups is contrary to the spirit and letter of the EC directives. He also criticizes the bill for failing to allocate responsibility for accidents.

Borillo says that the bill should have imposed an obligatory insurance on manufacturers to cover the risks of their products, as in other EC countries. But he claims that the government has bowed to pressure from industry to protect its operating costs.

Many scientists are also unhappy that the bill was drafted behind closed ministry doors. Emilio Munõz, former president of CSIC, Spain's main research organization, and now based at Madrid's Institute of Social Studies, says that a wider public debate is needed.

Luis Angel Fernandez

\section{UK report criticizes EC directives}

ments made at the time they were drafted.

It calls for the government to push for amendments to the directives, making them less onerous on industry, and argues strongly against the idea that socio-economic need - the so-called 'fourth hurdle' — be taken into account when assessing new safety regulations.

Unsurprisingly, the report has received a warm welcome in the biotechnology industry. In contrast, there has been a more lukewarm response from those responsible for implementing the existing regulations.

John Beringer, for example, professor of molecular genetics at the University of Bristol, and chairman of the Advisory Committee on Releases to the Environment, points out that a number of steps have recently been introduced to streamline the application procedures for experiments and reduce their burden on researchers. 